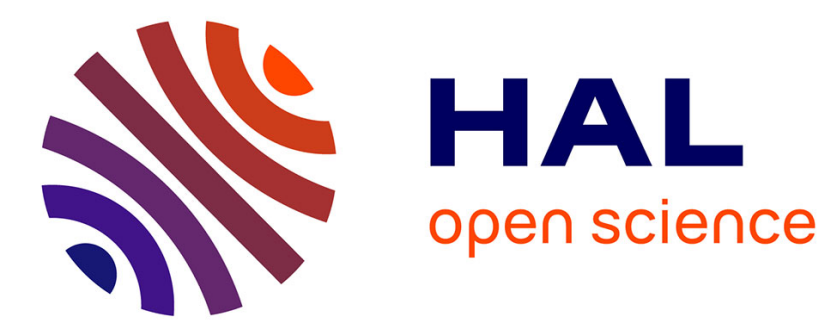

\title{
Victimization surveys on university campuses: a spatial comparison
}

\author{
Pierre-Olivier Weiss
}

\section{To cite this version:}

Pierre-Olivier Weiss. Victimization surveys on university campuses: a spatial comparison. 20th ICTEL 2019 - International Conference on Teaching, Education \& Learning, Oct 2019, Dubaï, United Arab Emirates. hal-02344119

\section{HAL Id: hal-02344119 https://hal.science/hal-02344119}

Submitted on 3 Nov 2019

HAL is a multi-disciplinary open access archive for the deposit and dissemination of scientific research documents, whether they are published or not. The documents may come from teaching and research institutions in France or abroad, or from public or private research centers.
L'archive ouverte pluridisciplinaire HAL, est destinée au dépôt et à la diffusion de documents scientifiques de niveau recherche, publiés ou non, émanant des établissements d'enseignement et de recherche français ou étrangers, des laboratoires publics ou privés. 


\title{
Victimization surveys on university campuses: a spatial comparison
}

Pierre-Olivier Weiss

Marseille, France

Laboratoire méditerranéen de sociologie (UMR 7305)

20th ICTEL 2019 - International Conference on Teaching, Education \& Learning, 06-07 October, Dubai

\begin{abstract}
Based on victimization surveys conducted on the university campuses of the city of Marseille, this article reveals the nature of the facts of delinquency and incivility as perceived by users, showing that they differ according to the urban location of these particular educational spaces. The results of the survey make it possible to highlight the prevalence of victimization and the profile of victims, but also to give a measure of the feeling of insecurity in an institution that welcomes a significant proportion of young people. This presentation proposes to fill a scientific gap in knowledge of the student world at a time when the issues of securing these public places are the subject of much debate.
\end{abstract}

Key words: students, university campus, victimization, fear of crime, security.

\section{Introduction}

The recent hashtag movement \#pasdevague on Twitter, reminds us of the current situation of the issue of "violence" in educational institutions, but also how emotionally charged this theme is. While it has made it possible to make the failures of the "sanctuary" school (this republican creature where "external noises do not enter", as desired by the pedagogue Alain, 1978, p. 877) publicly visible, it has also highlighted the inconsistencies of the public processing of data provided to institutions and the imperfection of the instrument for counting victims and perpetrators. Moreover, while researchers are interested in victimization in secondary education (Debarbieux, 2004), we have very little evidence to discuss victimization of higher education students, although campuses are social spaces where student numbers continue to increase each year (see also Cacouault-Bitaud and Euvrard, 2009).

In France, the public debate is fed by a single statistical source: police and gendarmerie statistics. However, researchers have developed general population surveys, a key tool in the social sciences when considering this subject. The genesis of investigations into victimization and feelings of insecurity can be found in the United States, where security concerns date back to the 1960s with the President's Commission on Law Enforcement and Administration of Justice (Katzenbach Commission). In 1965, the first statistical victimization studies, independent of the various federal administrations, were carried out. They will continue while improving their samples every five years starting in 1973. Thus, the focal length is reversed in order to position oneself from the victim's point of view and it is quickly observed that the reported victimizations are far higher than those recorded by the administrative services. Following the momentum of North American studies, social science researchers in France are taking advantage of this method of investigation (Zauberman, Robert, Beck and Névanen, 2013). The victimization survey then becomes the main measurement tool based on samples to which the sampling technique is applied. The aim is to gauge "a social phenomenon that has traditionally been measured only through administrative data" (Zauberman, 2015, p. 8). The 1980 s, under the influence of American research, marked a major turning point when the two conceptions on the feeling of insecurity were analysed separately. At that time, work on fears grew under the impetus of the Centre de recherches sociologiques sur le droit et les institutions pénales (CESDIP). Many studies will develop in the following decades on very varied subjects with the creation of several specialized research centres on crime. Since the mid-1980s, the State has been promoting several sectors of research on crime through the establishment of structures and bodies, such as the French Observatory for Drug Addiction (OFDT) and the National Institute for Higher Security and Justice Studies (INHESJ). This period is marked by 
a strong use of quantitative data in a context of public procurement "in connection with the growing importance of statistics and "expertise" in the public debate" (Mucchielli, 2004, p. 36). Within this profusion of research on crime knowledge, victimization surveys will be implemented among the French population. Today, they are entering the field of sociology of higher education.

The studies of the Observatoire de la vie étudiante (which focus on the living conditions of students in France) provide elements that provide a better understanding of the perception of inequalities (Ferry and Tenret, 2017), vulnerability (Cordazzo, 2016) and student isolation (Belghith, Giret, Ronzeau and Tenret, 2017), but leave out victimizations. After several decades of research on students (Bourdieu and Passeron, 1964; Levy-Garboua, 1976; Baudelot, Establet, Benoliel and Cukrowicz, 1981; Lapeyronnie and Marie, 1992; Eicher and Gruel, 1996; Felouzis, 2001 ; Coulon, 2005; McInnis, 2004), apart from the study of discrimination, we have no data available on the experience of victimization and fears felt on French campuses.

\section{University campuses: object and field}

In this context, we have an original field of investigation, those particular places of social life that are university campuses on which no such research has been conducted in France. Our research subject has different characteristics.

\subsection{The university campus: a particular place of social life}

First of all, university campuses in France are still located in urban areas, either in the heart of city centres or increasingly on the outskirts. The evolving links between territories and universities must be examined. From a general point of view, the relationship between universities and their territory ranges from divorce in the mid-1980s, when local communities cared little about it (degraded, aging campuses deserted by students as soon as classes ended), to reconciliation following the 2000 University Plan launched in the 1990s by the Jospin government. Within urban territories, universities are then seen as an economic, social and cultural asset, thus breaking out of their isolation from local society. In reality, the relationship between the city and the university alternates phases of rapprochement and empowerment according to various developments, including student numbers. At the time, Dubet and his colleagues pointed out that "from the early 1960s, the tremendous growth in student numbers would break up the university palaces of the late 19th century and call into question the inadequacy between the university network and new urbanization" (Dubet, Filatre, Merrien, Sauvage \& Vince, 1994, p. 24) In addition, the campus was also a place of sociability for an increasingly numerous group of young people. Indeed, the number of students enrolling in university increased considerably between 1960 and 2015, from 310,000 to 2,910,000. This phenomenon, which peaked at the turn of the 1980s and 1990s, is confirmed for the recent period (2016 and 2017) for both the public $(+4 \%)$ and private $(+2.8 \%)$ sectors. As time goes by, higher education becomes more and more attractive for baccalaureate holders and this attractiveness is combined with the extension of the duration of studies. Nevertheless, over the last twenty years, the influx of foreign students has contributed to the increase in overall enrolment. The latter represented 12.1\% of students in 2013 (MESRI, 2017: 29). University campuses can also be viewed through the specificity of student life and its constraints. Indeed, the relationship to studies, travel time, paid time or even relations between students are some of the characteristics of student life.

Today, almost all general baccalaureate holders and almost three-quarters of technological baccalaureate holders are enrolled in university. Considering the share of an age group that obtains a baccalaureate and the growing proportion that continues its studies in higher education, about $60 \%$ of young people study in one of the courses of higher education. Nationally, $58 \%$ of $20-24$ years old are engaged in higher education, from all social backgrounds. This democratization concerns in particular the children of workers and employees who gradually enter university, although the gap between the most and least 
privileged remains: $74 \%$ of children in managerial and intermediate professions are graduates of higher education compared to $38 \%$ of children of workers or employees over the period 2013-2015. In 2016, children of managers and higher intellectual professions are overrepresented (36\%) in higher education (Belghith, Giret, Ronzeau and Tenret, 2017, p. 2) compared to their proportion (18\%) in the working population (INSEE, 2016). Moreover, women have made a breakthrough in higher education since they are now in the majority $(55 \%)$ and completely dominate the Humanities and Social Sciences fields (70\%). On the other hand, they are proportionally less numerous in scientific fields, very selective fields, and among doctoral students. In the end, the university represents $62 \%$ of the student population, which means that it is far ahead of the IUT and the Grandes Écoles. In 2015, students receiving direct financial assistance in the form of grants or loans amounted to 710,000 ( $€ 6$ billion). The increase in the population has as a corollary its diversification in terms of living conditions as well as its social characteristics. The triennial study by the Observatory of student life (OVE) shows an increasing sense of integration of students into the life of their institution; $39 \%$ said they were fully integrated in 2016 compared to 34\% in 2013 (Belghith, Giret, Ronzeau and Tenret, 2017, p. 3). In 2016, students received their financial resources (89\% of students) in three different but sometimes complementary ways: income from paid employment $(33 \%)$, public assistance (31\%) and family assistance (25\%). In total, as in $2013,46 \%$ of them were employed during their studies (Belghith et al., p. 5), earning an average of $€ 704$ per month. This income has increased by $122 €$ over the last three years. While almost half of the students work to finance their studies, one part is involved in an activity related to the studies they are studying (15\% of employees) and another is involved in an internship or work-study program $(30 \%)$. Nevertheless, $36 \%$ of them have a paid activity not related to studies, most often part-time over six months (Belghith et al., p. 6). Although there is a decrease between 2013 and 2016 (-8 points), $57 \%$ of scholarship students still say they "do not have enough money to cover their needs". There is no significant change in the way students live between 2013 and 2016: "as in 2013, one third of students [are accommodated] at their parents' home and one third of them live in rental accommodation, alone or with a partner. Among the other types of accommodation, shared accommodation and accommodation in university residence also remain stable for $11 \%$ and $12 \%$ of students respectively" (Belghith et al., p. 8). Finally, the SEW study makes a significant contribution to the health status of students, stating that if it is considered satisfactory overall, psychological fragility increases. Indeed, although two-thirds of those surveyed in 2016 said they were satisfied with their health status, women, roommates, foreign students and students of working class origin were generally less satisfied with their health conditions. For example, $58 \%$ of students from the most vulnerable social classes say they are satisfied with their health. Ultimately, reports of suffering for one of the symptoms increased ( +6 points) (Belghith \& al., Chart 8, p. 9). Students are also more likely than the general population to deprive themselves of medical care (13\% for financial reasons). The 2325 age group is the most affected, which is explained by the gap in which this age group finds itself and acts as a double process: the family ceases to play its protective role and protection from work is not yet effective for the self-employed.

\subsection{Aix-Marseille University: territorial specificities}

As of January 1, 2019, the number of universities in France stood at 70. Faced with this proliferation, Aix-Marseille University (AMU), the largest university in France and the largest in the French-speaking world, constitutes a privileged field of research. AMU is divided into five campuses, four of which are located in Marseille, the fifth taking place in the city of Aixen-Provence. This first major subdivision masks the spread of the various sites, which number 54 throughout the PACA region. We will focus here on three of the Marseille campuses ( $c f$. fig.1). 


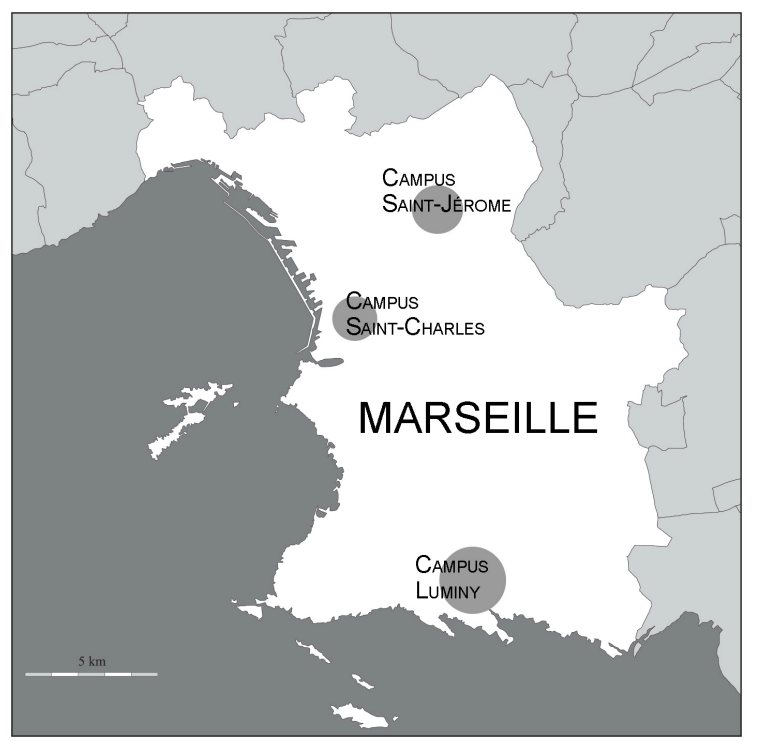

Figure 1. Location of the Marseille campuses.

AMU was created in 2012 following the merger of the three public universities in the region (Université de la Méditerranée, Université de Provence, Université Paul Cézanne), a process initiated by the law no 2007-1199 of 10 August 2007 on the freedoms and responsibilities of universities (the so-called LRU law or the Pécresse law). The ambition of one of the youngest French universities is evolving internationally (10,000 foreign students). It is currently the busiest in France (74,000 students enrolled) and even the largest French-speaking campus in the world for at least two reasons: number of students and budget. In the first place, it is only their embedding in the urban fabric that distinguishes the three campuses studied. First of all, the Luminy campus is located in a special geographical location within the Calanques National Park, in a southern peri-urban area, very far from the city center and away from any major business center. Secondly, the Saint-Charles campus is very much part of the urban space, finding a central place in the city, wedged between the SNCF station, the bus station and the Autoroute du Soleil. Third, the northern neighborhoods, a peripheral space, impoverished and in the process of urban restructuring in recent years, are home to the Saint-Jérôme campus. Consequently, this territorial diversity underlines the interest of the analysis that will follow. These different aspects led us to these three campuses to measure the victimations suffered and the fears felt by the students.

\section{Methodology}

Based on American research, particularly in the context of the Crime and Safety Survey Program (Fleury DeVoe \& Bauer, 2011; Barrett, Jennings \& Lynch, 2012; Sloan, Fisher, Cullen, 1997; Simon, 1994), and on the tradition of French surveys (Robert and Zauberman, 2011, 2017), this Marseilles university context has been the subject of victimization surveys.

Within these multiple debates exacerbating the security theme, certain categories of population and certain territories particularly concentrate these discourses and representations charged with fantasies (Mucchielli, 2001). Among all urban territories, the French suburbs are the subject of the greatest stigmatization, accumulating, through the prism of security, the most negative representations. This mechanism, which stigmatizes specific territories, is also particularly intense in the city of Marseille, now the second most populated city in France with about 866,600 inhabitants where socio-spatial contrasts are striking (INSEE, 2016; see also Donzel and Bresson, 2007, p. 90). A city considered in many respects to be a bad student at the national level, sometimes described as indomitable or rebellious (Dell'Umbria, 2006), is often overwhelmed by both the government and the national media more than the concrete reality of delinquent or criminal acts suggests (Mucchielli, Raquet, Saladino and Raffin, 2014). Marseille is subject to politicization and media coverage that embraces everything related to delinquency 
or crime to the point of talking about a Marseille Bashing (Mucchielli, 2015). These very negative representations are concentrated in the northern districts of the city (Pujol, 2016) where the "shit districts" contrast sharply with the "chic districts". Within the multiple social spaces, we seek to study university campuses under the aspects of victimization and insecurity by posing the hypothesis that these aspects maintain a link with their integration into the urban fabric. The campuses selected for their different socio-spatial locations on the scale of the city of Marseille allow this hypothesis to be tested. ORDCS ${ }^{1}$ was used to support this groundbreaking field survey.

\subsection{General considerations}

Given the size of this university, it was necessary to make a selection based on several criteria. It seemed interesting, from a comparative perspective, to focus on a single geographical area. The concentration of $80 \%$ of the sites in the Phocaean city predestined the latter to be chosen. Aix-en-Provence, another campus that was nevertheless important, particularly because of its size, was left out. In addition, it was appropriate to focus only on the city of Marseille in order to ensure comparability, coherence and homogenization. The simple criterion of the differentiated national reputation of these two urban nuclei is sufficient to understand the extreme heterogeneity at different levels of these two cities between which a "battle of the centers" is being fought (Peraldi, 2015, p. 95). Finally, the selection of sites was also based on the strong contrasts in the socio-spatial location of the three university campuses mentioned above.

The main objective is to highlight and compare the acts of delinquency to which students on Marseilles campuses may have been victims during an academic year, whether or not they have informed the central administrative services or the police and gendarmerie. The victimization survey has the advantage of allowing a count of victims, but also an evaluation of the feeling of insecurity. In the continuum of discussions and debates on security over the past forty years, it is necessary to distinguish between opinions, risks of victimization and feelings of insecurity. The initial problem is to detach oneself from common sense and break with the preconceptions about the phenomenon. On this emotionally charged subject, the evidence often contains misleading representations. As such, Duprez and Hedli's (1992) qualitative research in the North highlights the dichotomy between individuals who are afraid of crime and those who are only concerned about it. In short, we must not confuse the distinct mechanisms of fear and concern, the first refers to a feeling, the one we are seeking to know, while the second expresses an opinion. Fear can be considered as "an apprehension of risk" in partial association with local delinquency (Pottier and Robert, 1997) or with reported victimizations (Pottier, Zauberman and Robert, 2002). The second dimension of the sense of insecurity lies in the concerns about delinquency, which are being raised to the level of an important, even a priority social problem.

\subsection{The questionnaire}

At the beginning of the survey, we considered the biases associated with generalized individual computerized procurement as ultimately high to introduce it. Indeed, the risk seemed too great to seize a mass of students who saw in the victimization survey a way to report observed acts or delinquency. It was necessary to lock at the source the affect and other sources of emotion that this type of study can generate. The use of a so-called on-the-fly questionnaire was also to be excluded since, once again, respondents are asked to participate on a voluntary basis.

To do this, the idea was to negotiate upstream with the department heads, then more directly with the teachers, to use a quarter of an hour of the course time - a period when the student is available - to deploy our questionnaire and thus reach masses of "captive" students, but also to reach the whole person. In other words, both victims and non-victims had to be addressed. It

\footnotetext{
${ }^{1}$ The scientific research programme called the Observatory of Delinquency and Social Contexts ran from 2011 to 2015 under the direction of sociologist Laurent Mucchielli, research director at the CNRS and specialist in deviance phenomena and security policies.
} 
should be noted that we intervened in courses where attendance was mandatory in order to capture a subset of the student population with heterogeneous socio-economic and academic characteristics. In this way, we generally collected the declarations of the Bachelor's students at different times of the day by varying the days of the week (Monday to Friday). In this case, the only method of procurement was the paper questionnaire. Then, the technique of collecting the responses of the Masters (smaller promotions) is summed up in a computerized handover of an identical questionnaire in the computer room, most often in our presence in order to orally introduce the study conducted; a method that facilitated the coding of the data and reduced the time consuming aspect of our research system. The doctoral students were investigated by sending an email ( 2 reminders), sometimes by the doctoral schools, sometimes by research directors, and sometimes by us via lists obtained from the laboratory directors. But each time, the electronic link was sent with a text specifying our request and the framework within which it was made. Then, in general, we favored closed-ended questions in order to avoid another potential bias. Indeed, the excess of open-ended questions in a questionnaire tends to cause respondent fatigue and increase avoidance behaviors for some questions, coupled with an approximation in the answers, making final exploitation more difficult. About ten minutes to submit to the questionnaire was the maximum appropriate time considered, a limited time that we took into account during the design work. Finally, victimization surveys ask about the past, usually the previous year or the two previous years. Consequently, the temporality was determined on the academic year preceding our study. If the respondents' statements are based on their memories, the event in question must also be perceived by the victim as a victimization and the victim must be able to verbalize it. Despite these pitfalls and the absence of a perfect instrument, victimization surveys are those that most closely approximate the reality at a given time on a specific population, while the statistics of criminal institutions largely reflect their activity, whose priorities change over time. Comparison with other available sources is a way of checking for matches or discrepancies and possibly showing trends. In short, "a film says more than a photography" (Zauberman, 2015, p. 11).

After collecting the socio-demographic characteristics of the respondents (age, sex, place of residence, year of registration, grant allocation, income level, mode of transport), a first section of the questionnaire questions the satisfaction of the study environment through 4 indicators (drugs, acts of vandalism, site cleanliness, lighting). The second section of the questionnaire focuses on the fears expressed on and around campuses during the day, at night and during the home-university journey. The declaration of a victimization takes place in a last general section. The initial question is formulated as follows: During the previous academic year, were you a victim of any of the following incidents? There are then 7 potential victimizations (Theft or attempted theft of your car or two-wheelers; Theft or attempted theft of an object in or on your car, Voluntary act of vandalism on your car or two-wheelers, Theft or attempted theft with or without violence of personal object(s); Insults or verbal threats; Discrimination; Physical violence or attempt). Thus, students who declare themselves victims (filters) are then invited to answer one or more modules (if they declare several different victimizations) that specify the frequency, temporality and location of the victimization. Then, victims are asked for information about the perpetrators (if identified) and their behavior after the fact (simple reporting, handrail, complaint). In the case of multivictimization on the same item, the respondent is informed that we are only interested in the last fact that he or she suffered.

The period studied is from September 2012 to June 2015. The corpus is composed of 1,250 usable questionnaires: 529 people in Luminy (6\% of students), 364 in Saint-Charles $(22 \%$ of students) and 357 in Saint-Jérôme (11\% of students). The collection of questionnaires was large enough to allow statistical adjustment of the sample based on SEW data on the following sociodemographic variables: sex, age, year of enrolment, whether or not they were scholarship recipients, place of residence. In the study of the victimations we present, we have chosen to speak in terms of confidence intervals. Indeed, the confidence interval reflects the statistical accuracy of the result and appears in the tables below as percentages in square brackets. Thus, 
rather than punctually estimating the true unknown value of the parameter $\theta$ (victim rate), we looked for an interval that "most likely" covered this true value.

\section{Results}

\subsection{Population}

The Luminy campus has 14,000 students for the 2013-2014 academic year, $42 \%$ of whom are women and $58 \%$ men. The latter are mainly aged between 20 and 24 years old and reside mainly in their study city. A quarter of the students holds a scholarship.

\begin{tabular}{|l|c|c|c|}
\cline { 2 - 4 } \multicolumn{1}{c|}{} & $\begin{array}{c}\text { Before } \\
\text { adjustment }\end{array}$ & $\begin{array}{c}\text { After } \\
\text { adjustment }\end{array}$ & $\begin{array}{c}\text { Difference in } \\
\text { absolute value }\end{array}$ \\
\hline Men & $41,8 \%$ & $42,0 \%$ & $-0,2 \%$ \\
& $58,2 \%$ & $58,0 \%$ & $0,2 \%$ \\
\hline Under 20 years old & & & \\
20-24 years old & $9,6 \%$ & $18,3 \%$ & $-8,7 \%$ \\
$\mathbf{2 5 - 2 9}$ years old & $73,7 \%$ & $69,8 \%$ & $3,9 \%$ \\
30 years and over & $14,2 \%$ & $10,1 \%$ & $4,1 \%$ \\
\hline & $2,5 \%$ & $1,8 \%$ & $0,7 \%$ \\
\hline In Marseille & & & \\
Outside Marseille & $86,0 \%$ & $54,3 \%$ & $31,7 \%$ \\
\hline & $14,0 \%$ & $45,7 \%$ & $-31,7 \%$ \\
\hline Scholarship recipients & & & \\
Non-Scholarship recipients & $33,7 \%$ & $25,0 \%$ & $8,1 \%$ \\
\hline
\end{tabular}

Table 1: Profiles of the Luminy students before and after adjustment. Academic year 2013-2014. Sources: Luminy survey, OVE, 2013.

On the second campus, Saint-Charles, there were 3,275 students during the same period, 47\% of whom were scholarship recipients, divided between $52 \%$ women and $48 \%$ men, mainly aged between 20 and 24 .

\begin{tabular}{|l|c|c|c|}
\cline { 2 - 4 } \multicolumn{1}{c|}{} & Before adjustment & After adjustment & $\begin{array}{c}\text { Difference in absolute } \\
\text { value }\end{array}$ \\
\hline Men & $50,5 \%$ & $51,8 \%$ & $-1,3 \%$ \\
Women & $49,5 \%$ & $48,2 \%$ & $1,3 \%$ \\
\hline & & & \\
\hline Under 20 years & $15,4 \%$ & $8,1 \%$ & $7,3 \%$ \\
old & $72,3 \%$ & $55,0 \%$ & $17,3 \%$ \\
$\mathbf{2 0 - 2 4}$ years old & $10,7 \%$ & $22,0 \%$ & $-11,3 \%$ \\
$\mathbf{3 0}$ years and over & $1,6 \%$ & $14,9 \%$ & $-13,3 \%$ \\
\hline & & & $0,6 \%$ \\
\hline Bac+2 & $38,5 \%$ & $37,9 \%$ & $8,7 \%$ \\
Bac+3 & $34,3 \%$ & $25,6 \%$ & $0,4 \%$ \\
Bac+4 & $11,5 \%$ & $11,9 \%$ & $7,8 \%$ \\
Bac+5 & $14,3 \%$ & $6,5 \%$ & $-16,6 \%$ \\
More than bac+5 & $1,4 \%$ & $18,0 \%$ & \\
\hline
\end{tabular}




\begin{tabular}{|l|c|c|c|}
\hline & & & \\
\hline $\begin{array}{l}\text { Scholarship } \\
\text { recipients }\end{array}$ & $41,5 \%$ & $31,1 \%$ & $10,4 \%$ \\
$\begin{array}{l}\text { Non-Scholarship } \\
\text { recipients }\end{array}$ & $58,5 \%$ & $68,9 \%$ & $-10,4 \%$ \\
\hline
\end{tabular}

Table 2: Profiles of the Saint-Charles students before and after adjustment. Academic year 2013-2014. Sources: Saint-Charles survey, OVE, 2014.

The Saint-Jérôme campus is the third field and has about 3,500 students. The most represented ages on the three fields are also the 20-24 years old living in Marseille. Unlike the other two campuses, there are proportionately more women here. In addition, nearly half of the students are scholarship recipients.

\begin{tabular}{|c|c|c|c|}
\hline & $\begin{array}{c}\text { Before } \\
\text { adjustment }\end{array}$ & $\begin{array}{c}\text { After } \\
\text { adjustment }\end{array}$ & $\begin{array}{l}\text { Difference in } \\
\text { absolute value }\end{array}$ \\
\hline $\begin{array}{l}\text { Men } \\
\text { Women }\end{array}$ & $\begin{array}{l}60,0 \% \\
40,0 \%\end{array}$ & $\begin{array}{l}58,8 \% \\
41,2 \%\end{array}$ & $\begin{array}{c}1,2 \% \\
-1,2 \%\end{array}$ \\
\hline $\begin{array}{l}\text { Under } 20 \text { years old } \\
20-24 \text { years old } \\
25-29 \text { years old } \\
30 \text { years and over }\end{array}$ & $\begin{array}{c}1,1 \% \\
62,8 \% \\
26,7 \% \\
9,5 \%\end{array}$ & $\begin{array}{c}10,9 \% \\
67,2 \% \\
19,3 \% \\
2,5 \%\end{array}$ & $\begin{array}{c}-9,8 \% \\
-4,4 \% \\
7,4 \% \\
7 \%\end{array}$ \\
\hline $\begin{array}{l}\text { Bac+2 } \\
\text { Bac+3 } \\
\text { Bac+4 } \\
\text { Bac+5 } \\
\text { More bac+5 }\end{array}$ & $\begin{array}{l}26,1 \% \\
25,1 \% \\
15,6 \% \\
19,0 \% \\
14,2 \% \\
\end{array}$ & $\begin{array}{l}25,2 \% \\
23,5 \% \\
23,5 \% \\
16,0 \% \\
11,8 \% \\
\end{array}$ & $\begin{array}{c}0,9 \% \\
1,6 \% \\
-7,9 \% \\
3 \% \\
2,4 \% \\
\end{array}$ \\
\hline $\begin{array}{l}\text { Scholarship recipients } \\
\text { Non-Scholarship recipients }\end{array}$ & $\begin{array}{l}26,8 \% \\
73,2 \% \\
\end{array}$ & $\begin{array}{l}47,1 \% \\
52,9 \% \\
\end{array}$ & $\begin{array}{l}-20,3 \% \\
20,3 \% \\
\end{array}$ \\
\hline $\begin{array}{l}\text { In Marseille } \\
\text { Outside Marseille }\end{array}$ & $\begin{array}{l}60,1 \% \\
39,9 \%\end{array}$ & $\begin{array}{l}89,9 \% \\
10,1 \%\end{array}$ & $\begin{array}{l}-29,8 \% \\
29,8 \%\end{array}$ \\
\hline
\end{tabular}

Table 3: Profile of the Saint-Jérôme students before and after adjustment. Academic year 2015-2016. Sources: Saint-Jérôme survey, OVE, 2016.

\subsection{Comparative prevalence of victimization}

We are interested in the prevalence of victimization, i.e. the proportion of people affected at least once by a type of victimization during the reference period (the most reliable indicator). The double entry table presented below provides three data blocks. First, the percentages of non-victims and victims are shown, and second, the reported victimizations. This division is reminiscent of the fact that too often the categories that have little to do with each other are referred to as "delinquency". Certainly, how can an insult, a threatening look and a physical assault or even a vehicle theft be examined in a similar way? There are many delinquencies that need to be dealt with accordingly. This is why it is obvious that a separation is necessary to avoid amalgamating very heterogeneous victimizations. Finally, thirdly, a section is dedicated to the personal frequency of victimizations, this time by dissociating victims on a single occasion and multivictims. 


\begin{tabular}{|c|c|c|c|}
\hline & $\begin{array}{c}\text { Luminy } \\
\text { (Field 1) } \\
\text { Intervals in \% }\end{array}$ & $\begin{array}{l}\text { Saint-Charles } \\
\text { (Field 2) } \\
\text { Intervals in \% }\end{array}$ & $\begin{array}{l}\text { Saint-Jérôme } \\
\text { (Field 3) } \\
\text { Intervals in \% }\end{array}$ \\
\hline Not Victims & $\begin{array}{c}{[77,0 \% ; 83,7 \%]} \\
80,3 \%\end{array}$ & $\begin{array}{c}{[73,5 \% ; 82,0 \%]} \\
77,7 \%\end{array}$ & $\begin{array}{c}{[58,8 \% ; 75,7 \%]} \\
67,2 \%\end{array}$ \\
\hline Victims & $\begin{array}{c}16,3 \% ; 23,0 \%] \\
19,7 \% \\
\end{array}$ & $\begin{array}{c}{[18,0 \% ; 26,5 \%]} \\
22,3 \% \\
\end{array}$ & $\begin{array}{c}{[24,3 \% ; 41,2 \%]} \\
32,8 \% \\
\end{array}$ \\
\hline Discrimination & $\begin{array}{c}{[3,9 \% ; 7,9 \%]} \\
5,9 \%\end{array}$ & $\begin{array}{c}{[4,0 \% ; 9,1 \%]} \\
6,6 \%\end{array}$ & $\begin{array}{c}{[2,8 \% ; 12,3 \%]} \\
\mathbf{7 , 6 \%}\end{array}$ \\
\hline $\begin{array}{l}\text { Theft or attempted theft of } \\
\text { objects from or on the car* }\end{array}$ & $\begin{array}{c}{[2,8 \% ; 7,9 \%]} \\
5,4 \%\end{array}$ & $\begin{array}{c}{[1,5 \% ; 11,4 \%]} \\
6,5 \%\end{array}$ & $\begin{array}{c}{[11,0 \% ; 34,8 \%]} \\
22,9 \%\end{array}$ \\
\hline Insults or verbal threats & $\begin{array}{c}{[3,2 \% ; 7,0 \%]} \\
5,1 \%\end{array}$ & $\begin{array}{c}{[10,2 \% ; 17,3 \%]} \\
13,7 \%\end{array}$ & $\begin{array}{c}{[6,0 \% ; 17,6 \%]} \\
11,8 \%\end{array}$ \\
\hline $\begin{array}{l}\text { Voluntary act of vandalism } \\
\text { on cars or motorized two- } \\
\text { wheelers** }\end{array}$ & $\begin{array}{c}{[2,8 \% ; 7,3 \%]} \\
5,1 \%\end{array}$ & $\begin{array}{c}{[1,6 \% ; 10,0 \%]} \\
\mathbf{5 , 8 \%}\end{array}$ & $\begin{array}{l}{[0 \% ; 7,7 \%]} \\
\quad 3,9 \%\end{array}$ \\
\hline $\begin{array}{l}\text { Theft or attempted theft } \\
\text { WITH or WITHOUT violence of } \\
\text { personal object(s) }\end{array}$ & $\begin{array}{c}{[\mathbf{2 , 5 \%} ; \mathbf{5 , 9 \%} \mathbf{0}} \\
4,2 \%\end{array}$ & $\begin{array}{c}{[1,3 \% ; 4,8 \%]} \\
3 \%\end{array}$ & $\begin{array}{c}{[1,1 \% ; 9,0 \%]} \\
\mathbf{5 , 1 \%}\end{array}$ \\
\hline ... without violence & $\begin{array}{c}{[1,6 \% ; 4,5 \%]} \\
3,0 \%\end{array}$ & $\begin{array}{c}{[0,9 \% ; 4,1 \%]} \\
2,5 \%\end{array}$ & $\begin{array}{c}{[0,6 \% ; 7,8 \%]} \\
\mathbf{4 , 2 \%}\end{array}$ \\
\hline ... with violence & $\begin{array}{c}{[0,1 \% ; 1,8 \%]} \\
0,9 \%\end{array}$ & $\begin{array}{c}{[0 \% ; 1,3 \%]} \\
0,5 \%\end{array}$ & $\begin{array}{c}{[0 \% ; 2,5 \%]} \\
\mathbf{1 , 2 5 \%}\end{array}$ \\
\hline $\begin{array}{l}\text { Theft or attempted theft of a } \\
\text { car or motorcycle** }\end{array}$ & $\begin{array}{c}{[1,5 \% ; 5,2 \%]} \\
3,2 \%\end{array}$ & $\begin{array}{c}{[0,6 \% ; 7,7 \%]} \\
\mathbf{4 , 2 \%}\end{array}$ & $\begin{array}{c}{[0 \% ; 7,7 \%]} \\
3,9 \%\end{array}$ \\
\hline Physical violence or attempt & $\begin{array}{c}{[0,6 \% ; 2,8 \%]} \\
1,7 \% \\
\end{array}$ & $\begin{array}{c}{[\mathbf{1 , 5 \%} ; \mathbf{5 , 1 \%} \%]} \\
3,3 \%\end{array}$ & $\begin{array}{c}{[0,1 \% ; 6,6 \%]} \\
\mathbf{3 , 4 \%} \\
\end{array}$ \\
\hline Victims... & $\begin{array}{c}{[16,3 \% ; 23,0 \%]} \\
19,7 \%\end{array}$ & $\begin{array}{c}{[18,0 \% ; 26,5 \%]} \\
22,3 \%\end{array}$ & $\begin{array}{c}{[24,3 \% ; 41,2 \%]} \\
32,8 \%\end{array}$ \\
\hline ... only once & $\begin{array}{c}{[12,2 \% ; 18,4 \%]} \\
15,3 \%\end{array}$ & $\begin{array}{c}{[13,2 \% ; 20,9 \%]} \\
17,0 \%\end{array}$ & $\begin{array}{c}{[18,9 \% ; 34,9 \%]} \\
26,9 \%\end{array}$ \\
\hline ... several times & $\begin{array}{c}{[2,6 \% ; 6,1 \%]} \\
4,4 \%\end{array}$ & $\begin{array}{c}{[3,2 \% ; 7,8 \%]} \\
5,5 \%\end{array}$ & $\begin{array}{c}{[1,7 \% ; 10,1 \%]} \\
5,9 \%\end{array}$ \\
\hline
\end{tabular}

* Among students with a car.

** Among students with a motorized car and/or motorized two-wheelers.

Table 4: Prevalence of student victimization on all three campuses. University years 2012-2013 (Luminy, Saint-Charles) and 2014-2015 (Saint-Jérôme). Sources: Luminy surveys, 2013, Saint-Charles 2014, SaintJérôme 2016.

First of all, we can note in field 1 that about $80 \%$ of the students did not suffer any victimization. Moreover, among victims, the proportion of multivictims is $6 \%$. Since the rates are calculated on the persons concerned, the category "theft or attempted theft of objects from or on the car" is the second most common victimization after discrimination and before verbal insults or threats. Thus, $5.4 \%$ of students reported that they had been victims of theft or attempted theft of objects "in or on their car" during the 2012-2013 academic year.

Victims of discrimination - related to gender, skin color, religion - represent between $3.9 \%$ and $7.9 \%$ in the field 1 . Police statistics can only reflect this in an extremely measured way (no complaints). Then, the percentage of victims of verbal insults or threats is between $3.2 \%$ and $7 \%$. Here too, police statistics remain a poor tool for counting these types of victims, who are sometimes assumed to be muzzled both by their low confidence in the police to redress this injustice and by their own representations of the seriousness of the act. An insult or verbal threat 
may heal more quickly than a physical assault. We can agree that victims of physical violence are marginal (between $0.1 \%$ and $2.8 \%$ ).

In field 2, the general observation is similar since nearly $4 / 5$ of students $(77.7 \%)$ do not report any victimization. The victim rate and prevalence of multivictimization are slightly higher than that of field 1 . There is also a higher proportion of victims of "verbal abuse or threats" $(13.7 \%)$ and "discrimination" $(6.6 \%)$. The hypothesis of the trivialization of this delinquency and its institutional invisibility arises here as in Luminy. Thus, we considered that "insult exists when one feels insulted" (Moses, 2011, p. 30). In the same vein, "the insult is difficult to identify from a strictly linguistic point of view, because it takes a variety of forms" (Rosier, 2009, p. 42). Victims of physical violence (3.3\%) and robberies with or without violence $(3 \%)$ show a proportionally low prevalence rate. Despite a clear variation in prevalence rates between the first two fields, we are clearly faced with victims of crimes of very moderate seriousness, which excludes physical violence a priori. These observations are only partially reflected in our third field.

Indeed, the latter is somewhat different in that it shows a much higher rate of victims than the other campuses studied (32.8\%). Is there a "north of Marseille neighborhood effect" as often highlighted by local and national media where danger is omnipresent? The prevalence of multivictimization is also higher than elsewhere. In addition, victims of physical violence number around $5 \%$ of students. Concerning moral and psychological integrity, victims of verbal insults or threats $(11.8 \%)$ and discrimination $(7.6 \%)$ of all kinds are quite high in proportion. As for material damage, they focus on victimizations related to vehicles subject to theft (or attempted theft) of objects from or to the car $(22.9 \%)$. Finally, victims of theft (or attempted theft) of personal belongings account for around 5.1\%.

In general, students are more victimized on the Saint-Jérôme campus (32.8\%) than on SaintCharles $(22.3 \%)$ and Luminy $(19.7 \%)$. From this point of view, the Luminy campus seems to be the most preserved site for local and intra-university crime. Field 1 students also have the lowest prevalence of multivictimization (4.4\%). Concerning insults and verbal threats, the students of Saint-Charles, in front of Saint-Jérôme and then Luminy, are the most affected. This type of victimization relates first to verbal insults and threats and second to discrimination. For the latter victimization, it can be suggested, as in Ferry and Tenret (2017), that unequal treatment is related to university experience and in particular the level of integration of students, but it is difficult to determine the meaning of causality (p. 5). There are very few, if any, people who suffer physical violence, but Saint-Charles and Saint-Jérôme are different from Luminy. Would the geographical positioning of the two campuses in urban areas be used to understand the gaps? While our study examines acts of verbal and physical violence, we have not neglected property offences. Students in Saint-Jérôme account for by far the highest proportion of victims of object theft in or on the car. Nevertheless, victims of acts of vandalism on these same types of consumer goods are in greater proportion in Saint-Charles. From this initial decoding we can then study some victimations.

\subsection{Victimization study}

The aim here is to study the most numerically reported victimizations on the campuses investigated. We will provide information on the circumstances and characterization, first of all discrimination, secondly verbal insults and threats.

\subsubsection{The discriminations}

Discrimination is a type of victimization that has been questioned in an original way in the surveys developed by ORDCS (Mucchielli and Raquet, 2016). These three surveys conducted on university campuses in Marseille confirm the validity of this evolution of the questionnaires. Between $5.9 \%$ and $7.6 \%$ of students say they are victims of discrimination, half of them only once in the past year. In comparison, in 2016, more than one in five students surveyed reported 
being treated worse than their classmates (Cordazzo, 2016, p. 8). In addition, students are widely discriminated against in the context of inter-knowledge: $41 \%$ of victims say that these acts were committed by another student and $79 \%$ by a person known by sight. The alternation of day and night does not seem to have any effect on this type of victimization, but the afternoon is a privileged time (64\%). Contrary to popular belief, many criminal acts are perpetrated in broad daylight, although brightness has an impact on the fears felt and expressed (Mosser, 2007). In fact, these discriminations, which concern first of all sex (41.1\%) and then skin color (24\%), occur in areas where the flow of individuals is intense (university restaurant, cafeteria, university campus). More generally, we can think that this type of victimization is related to the lifestyle of young people (generally high sociability, various outings, visits to cultural and musical places, etc.). They are therefore potentially more exposed to it. The data used from the questionnaire showed that sexism is a discrimination that almost exclusively affects women (95\%), thus symbolizing "asymmetrical relations between the sexes" (Condon, Lieber \& Maillochon, 2005, p. 269).

The apparent incidence ${ }^{2}$ rate of discrimination is very low. Indeed, only $15 \%$ file a complaint and more than $50 \%$ do not report them. Sexism, which is based on a system of beliefs that are deeply rooted in the individual from the very beginning of primary socialization, often results from verbal interactions between peers. In our society, a large proportion of victimizations are silent, especially when they seem trivial to the victim or difficult to state. Similar results also emerge from a study conducted by Rizk in 2011 . Indeed, the complaint rate is also $15 \%$. There are determinants of the complaint rate and the type of victimization experienced distanced from the victim's profile (Chaussebourg, Creusat, Carrasco, 2011). This study shows that "the five types of personal violence, excluding sexual assault and within the household, observed in INSEE's Cadre de vie et sécurité (CVS) surveys are personal thefts and attempts, with and without violence, physical violence, threats and insults. They have extremely different complaint rates, from $3 \%$ for insults to $42 \%$ for robberies with violence" (Chaussebourg \& al., p. 107).

Skin color is the second discriminating attribute reported by respondents. This type of discriminatory attitude therefore raises the issue of "ordinary" racism, which extends far beyond the academic sphere, conceived as the place of relative social, ethnic and cultural diversity, of the daily experience of otherness. Rea and Tripier characterize it as follows: "If discrimination implies a relationship of power and domination, ordinary racism refers to the sphere of attitudes and opinions, and is declined differently according to social background" (Rea and Tripier, 2008, p. 74). It is in ordinary interactions that this type of racism is expressed. As such, in recent work based on qualitative and comparative research between Paris and Bogotá, Quintero (2013) shows that within French universities, black students suffer racial discrimination too often reduced by institutions. In general, discrimination ranks fourth (about $8 \%$ of respondents) among the victims reported by the inhabitants of Marseille between 2012 and 2013 (Mucchielli and Raquet, 2016), and primarily because of the color of their skin. It can be seen that even if these legally reprehensible behaviors are present at the city level, the university remains a place, it seems, less affected.

\subsubsection{Verbal insults and threats}

These categories used in the sociology of delinquency are primarily the concern of linguists, particularly when it comes to insults. On the severity scale, the insult appears less serious than the threat in terms of the intensity of the verbal aggression. Nevertheless, insults pose problems of definition because they proceed from a recategorization of the insulted person who attacks the image of himself/herself and remains linked to the symbolism of the verbal jousting, which a priori manifests a certain violence, but can also be conceived as a ritual interaction game

\footnotetext{
${ }^{2}$ Volume of victimization reported to the authorities.
} 
where language takes the form of a social weapon (Lepoutre, 1997). In fact, this relationship to verbal abuse refers to the notion of Face Threatening Acts (FTAs) popularized by Brown and Levinson (1987), building on the work of Goffman (1973).

This second type of incivility, which includes up to $61 \%$ of victims in Saint-Charles, occurs more in the afternoon (30\%) or at lunchtime (27\%), a little less often in the evening $(25 \%)$ and has only occurred in the case of one-third of victims. Most of the time, these are insults and not threats $(26 \%)$. When verbal aggression is proven, the authors act more in groups, in other words with the strength of numbers or the gang effect. The majority of them, in a quarter of the cases known to their victims, were unarmed at the time of the attack (71\%). A small majority of victims were killed at least twice during the study period. Victimization occurred on the student parking lot or much more frequently (twice as often in reality) on the way or in the vicinity of the university. It can therefore be assumed that these are daily incivilities between motorists, pedestrians or public transport users. American studies have also shown that off-campus incidents are relatively more violent and more frequent than on-campus incidents (Hart \& Miethe, 2011). The majority of victims remain silent and do not know the perpetrator overall. While only $1 \%$ of victims of insults or verbal threats go to the police station, $20 \%$ of them report to a security guard; trends already observed (CNCDH, 2017).

\subsection{Profile of victims}

We have so far focused on the acts of delinquency and incivility suffered by students, leaving aside their sociological characteristics. This has had the effect of masking part of the reality since the victims are not sociologically identical from one campus to another and represent specific strata of the population that need to be studied. Delinquency affects campus students in an unequal way. We present below the results of the logistic regressions in order to draw some lessons from them. Logistic regression is a technique called predictive. It aims to develop a model to explain the values taken by a qualitative target variable from a set of explanatory variables.

\subsubsection{Explanatory variables at victim rates}

To find explanatory variables for victim rates, we used cross tabulations and the Chi2 test. Cross-sorting and Chi2 testing highlight the existence (or not) of correlations between two random variables. In other words, the interdependence test allows us to determine, based on the results of our questionnaire, whether or not the observed value of one variable depends on the observed value of another variable. At the end of this test, we can draw up a "victim profile" containing all the recorded victimizations.

The socio-demographic variables tested on victims are as follows: gender, age, city of residence, place of residence, current curriculum, whether or not they hold a scholarship, and whether they receive an income. The variables tested on fear and sense of insecurity are: drug problems on campus, problems of vandalism on campus, cleanliness, maintenance of buildings and green spaces on campus, lighting, fear on campus during the day, fear on campus at night, fear on public transport to get to campus.

The tables below make it possible to study the probabilities of an event occurring in relation to a reference situation, using a "all other things being equal" reasoning. This makes it possible to estimate the effect of each factor on the variable of interest, i.e. the probability of being a victim of the damage studied. All these tests concede the existence of statistical links.

\subsubsection{On the Luminy campus}

Three variables emerge significantly in the logistic regression model: age, acts of vandalism, fear in the evening. First, 25-29 years old are almost 7 times more likely to be victims than those under 20. Secondly, the victims' perception of the environment is also particular. Students who describe acts of vandalism as significant on campus and in the neighborhood are 2.5 times more likely to be victims than those who consider them minimal. Finally, students who 
experience frequent fear when travelling at night on campus are almost 3 times more likely to be victims than those who are not or not very scared.

Odds-ratio

Risks of being a victim

\begin{tabular}{|l|l|l|l|l|}
\hline \multicolumn{2}{|l}{} & \multirow{2}{*}{$\begin{array}{l}\text { Estimated value } \\
\text { of the point }\end{array}$} & \multicolumn{2}{c|}{$95 \%$ Confidence interval of } \\
\cline { 4 - 5 } & & & Lower & \multicolumn{1}{|c|}{ Upper } \\
\hline \multirow{2}{*}{ Age } & $\begin{array}{l}20-24 \text { years vs. less than } \\
20 \text { years }\end{array}$ & 4.174 & 1.852 & 9.408 \\
\cline { 2 - 5 } & $\begin{array}{l}25-29 \text { years vs. under 20 } \\
\text { years }\end{array}$ & 6.599 & 2.463 & 17.685 \\
\cline { 2 - 5 } & $\begin{array}{l}30 \text { years and over vs. less } \\
\text { than 20 years old }\end{array}$ & 1.393 & 0.122 & 15.924 \\
\hline $\begin{array}{l}\text { Perception of acts } \\
\text { of vandalism }\end{array}$ & $\begin{array}{l}\text { Fair/Very important vs. } \\
\text { No/not important }\end{array}$ & 2.504 & 1.579 & 3.972 \\
\hline Fear at night & $\begin{array}{l}\text { Often/Always vs } \\
\text { Never/Sometimes }\end{array}$ & 2.869 & 1.484 & 5.547 \\
\hline
\end{tabular}

Table 5: Significant variables in the logistic regression model of all victims at Luminy. Academic year 2012-2013. Source: Luminy victimization survey, 2013.

\subsubsection{On the Saint-Charles campus}

Four variables emerge significantly in the logistic regression model: level of education, whether or not to have a scholarship, the drug problem and campus lighting. The $\mathrm{Bac}+5$ and $\mathrm{Bac}+3$ are almost 2.5 and 1.5 times more likely to be victims than the $\mathrm{Bac}+2$ and $\mathrm{Bac}+2$ respectively. Scholarship students are twice as likely to be victims as non-recipients. Students who describe drug problems on campus as quite significant and very important are twice as likely to be victims as those who give little importance to this phenomenon. Students with poor or unsatisfactory campus lighting are twice as likely to be victims as those who report the opposite.

Odds-ratio

Risks of being a victim

\begin{tabular}{|l|l|l|l|l|}
\hline \multicolumn{2}{|c|}{ Effect } & \multirow{2}{*}{$\begin{array}{l}\text { Estimated value } \\
\text { of the point }\end{array}$} & \multicolumn{2}{|c|}{$\begin{array}{c}\text { 95\% Confidence interval of } \\
\text { Wald }\end{array}$} \\
\cline { 4 - 5 } & & & \multicolumn{1}{|c|}{ Lower } & \multicolumn{1}{c|}{ Upper } \\
\hline \multirow{2}{*}{ Curriculum } & Bac+3 vs Bac+2 & 1.467 & 0.788 & 2.733 \\
\cline { 2 - 5 } & Bac+4 vs Bac+2 & 1.361 & 0.578 & 3.205 \\
\cline { 2 - 5 } & Bac+5 vs Bac+2 & 2.439 & 0.906 & 6.566 \\
\cline { 2 - 5 } & More than bac+5 vs Bac+2 & $<0.001$ & $<0.001$ & 3999.999 \\
\hline $\begin{array}{l}\text { Scholarship } \\
\text { recipients }\end{array}$ & Yes vs No & 2.087 & 1.198 & 3.635 \\
\hline $\begin{array}{l}\text { Perception } \\
\text { presence } \\
\text { drugs }\end{array}$ & $\begin{array}{l}\text { Fair/Very important vs. no/not } \\
\text { important }\end{array}$ & 1.909 & 1.001 & 3.639 \\
\hline $\begin{array}{l}\text { Perception } \\
\text { lighting of }\end{array}$ & $\begin{array}{l}\text { No/not satisfactory vs. } \\
\text { Fair/Very satisfactory }\end{array}$ & 2.384 & 1.371 & 4.144 \\
\hline
\end{tabular}

Table 6: Significant variables in the logistic regression model of all victims in Saint-Charles. Academic year 2013-2014. Source: Victimization survey Saint-Charles, 2014.

\subsubsection{On the Saint-Jérôme campus}

In the last field, the three variables that, all other things being equal, explain being victims are gender, current curriculum and fear in transport. First, men are 12 times more likely to be victims than women. Secondly, people enrolled in Master's degrees are almost 2.5 times more likely to be victims than people with 2 years of higher education. Third, students who have not 
been able to express their fears about transport are 13 times more likely to be victims than those who never say they are afraid when they use them.

Odds-ratio

Risks of being a victim

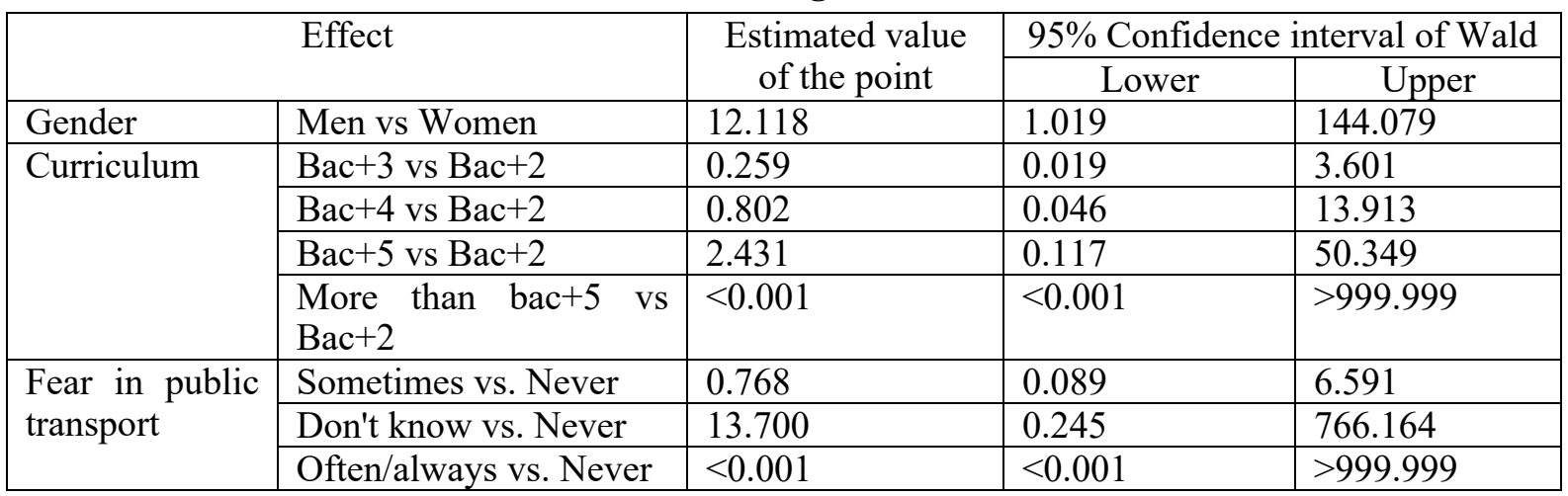

Table 7: Significant variables in the logistic regression model of all victims in Saint-Jérôme. Academic year 2015-2016. Source: Victimization survey Saint-Jérôme, 2016.

\subsubsection{Different victims on campuses}

The personal experience of moral, social or physical violence differs from one campus to another. First, the Saint-Jérôme campus, located in the city's northern neighborhoods, has the highest rate of victims without distinction of severity. Second, physical violence is by far the exception on all campuses with almost no prevalence. Indeed, students who are victims of insults, verbal threats and discrimination are the most important categories. On this point, the Luminy campus remains more preserved, probably because of its geographical position. Certainly, during the survey period, thefts (or attempts) of personal belongings occurred. But unlike the Marseilles clichés of the famous "snatching" which has been the subject of much ink in recent years, these thefts are non-violent and in the absence of the owner of the coveted property. This time, Saint-Charles has the most notable rates of damage to vehicles. Acts of violence, of very low magnitude, appear more clearly on the Saint-Charles and Saint-Jérôme campuses, in areas with high population density and pockets of identifiable poverty. When it comes to the theft of objects from cars, the Saint-Jérôme campus remains the first to be affected. Overall, given the low complaint rate, the invisibility of this small (or even very small) crime is very damaging to its eventual management by both the police and the university's central services.

In addition to the victimations experienced by students, we now focus on the feeling of insecurity that mixes both the perception of the living environment and what are called fears.

\section{Conclusion}

This research discussed the results of victimization surveys for students on three campuses. We have taken care to stress the importance of categorizing the acts of delinquency declared by students and to dissociate ourselves from an unfortunately (!) too widespread discourse on the evolutions or the current state of "delinquency". We have established a hierarchy of victimizations. From there, we saw that the Saint-Jérôme campus, located in the northern districts of Marseille, reported a percentage of victims that exceeded what can be seen in the city center (Saint-Charles) and in the Parc des Calanques (Luminy). From this point of view, the withdrawal of campuses from the city center, omitting all the concerns related to the eccentricity of a place of study and residence for some - how to get there, how to do your shopping, etc.? - largely protects against local crime. Also, the capacity of a campus has no influence on the level of recorded delinquency. More than the number of students on a campus, it is the type of incivility observed that seems to make the difference. While overall victimization rates on the campuses surveyed are lower than those recorded among the 
Marseille population - suggesting that the campus appears at first sight to be a more secure space - students are undoubtedly first affected in their moral and psychological integrity (insults, threats, discrimination). Interpersonal violence remains the exception. With regard to the theft of students' material goods, our results show that the objects in the car are the number one target of local crime and that it is students in outlying neighborhoods who suffer the most. The university must reposition itself as a space of socialization and as an institution, through its teachers and administrators, that must promote equality, open to its environment, open to society. The acts of discrimination identified take place largely within the framework of interknowledge, which suggests delinquency between users of the university site. Thus, the high proportion of discriminatory acts is partly the result of a lifestyle that exposes young people more than any other age in their lives. However, there is a card to be played here in terms of gender equality in particular and social cohesion as a whole, given the silence of the victims, which is sometimes assumed to emanate from fear, sometimes from indifference or even from a lack of trust in the institutions in order to reduce this major social phenomenon. Similarly, racism also finds expression in spite of the university ethos of both tolerance and diversity, which undoubtedly preserves this place of knowledge from its greater exacerbation in the rest of society. Ultimately, only victims of object theft tend to file complaints with the authorities. A significant discovery breaks with certain prejudices. Indeed, there is no result to suggest that the night period favours action, regardless of the victimization studied. The particularity of the downtown area is the high proportion of students who are victims of incivility around the university, suggesting scenes from everyday life where, when clashes occur, insults can be pronounced. Students on the North End campus are facing numerous attacks on property in their vehicles.

Students are statistically unequal in terms of delinquency, some categories of individuals are more exposed and affected by different types of delinquency. The statistical tools we have used provide an opportunity to highlight a series of correlations between the crime suffered and the socio-demographic characteristics of the victims. This set of correlations in turn offers the opportunity to draw a portrait of the victims. Students tend to define themselves as victims as their graduation and age increase. In general, the experience of victimization greatly increases the chances of often feeling insecure at night, but also of perceiving the study environment as degraded. Victims also report being more frightened when they travel or leave the campus at nightfall. Another correlation could be established between the victims of insults and the possession of a scholarship, suggesting a link between financial fragility and the experience of victimization. These data therefore offer us the possibility of targeting certain types of users in particular, in particular through prevention campaigns in which all education stakeholders are involved by building relationships that promote student involvement.

The predominant place of moral and psychological violence represents the other side of the coin, with sexism and racism at the top of the list. Moreover, when we talk about predation towards consumer objects, theft is mostly carried out in the absence of the victim, excluding in most cases verbal or physically violent interaction. In the end, the overall feeling of insecurity remains rather low. Fears are highly concentrated during the night, underlining the strength of the nocturnal imaginations that feed this feeling. All other things being equal, campus students in socially more favored areas are those who most often claim to be safe both in transportation and when travelling on campus. Conversely, the reputation of the urban center and the northern districts, conceived as a shared, temporary and localized social representation, associated with a name and resulting from more or less powerful and formalized social evaluations, has a social consistency and a character shared by a proportion of students. This way of looking at a neighborhood has the power to create fears without the reality of delinquency necessarily being the cause. These reflections lead us to rethink the question of the university climate as others have done before us on the school climate. Indeed, the latter is at the heart of the relationship to knowledge, of didactic and pedagogical interactions. The feeling of well-being as well as that of justice in the educational institution are crucial for the success of students. To think of 
the climate is to pose in another way the question of the relationship between socialization and learning through the question of the meaning of studies.

The questions that have been raised during this research relate largely to the question of social cohesion in these public spaces that are university campuses. The survey attempted to fill a scientific gap to improve the understanding of this student world. Future research will undoubtedly make it possible to consolidate these initial lessons concerning the nature of victimization and the feeling of fear.

\section{Bibliography}

Alain. (1978). Propos I. Paris : Gallimard.

Bajos, N., Bozon, M. \& l'équipe CSF (2008). Les violences sexuelles en France : quand la parole se libère. Population et sociétés, $\mathrm{n}^{\circ} 445$.

Barrett, K., Jennings W. \& Lynch M. (2012). The Relation Between Youth Fear and Avoidance of Crime in School and Academic Experiences. Journal of School Violence, 11(1), 1-20.

Baudelot, C., Establet, R., Benoliel, R. \& Cukrowicz, H. (1981). Les étudiants, l'emploi, la crise. Paris : Maspero.

Belghith, F., Giret, J.-F., Ronzeau, M. \& Tenret É. (02/2017). Panorama 2016. Conditions de vie des étudiants. OVE infos.

Bourdieu, P.\& Passeron, J.-C. (1964). Les héritiers : les étudiants et la culture. Paris : Éditions de Minuit.

Brown, P. \& Levinson, S. C. (1987). Politeness: Some Universals in Language Usage. Cambridge: Cambridge University Press.

Bursik, R. J. (1988). Social disorganization and theories of crime and delinquency. Criminology, 26, 519-551.

Cacouault-Bitaud, M. \& Euvrard, F. (2009). Sociologie de l'éducation. Paris : La Découverte. Mosser, S. (2007). Éclairage et sécurité en ville : l'état des savoirs. Déviance et Société, 31(1), 77-100.

Chaussebourg, L., Creusat, J. \& Carrasco, V. (2011). Les déterminants du dépôt de plainte : le type d'agression subie devance de loin les caractéristiques de la victime. Économie et statistique, $\mathrm{n}^{\circ} 448-449,107-127$.

CNCDH (3/2017). Rapport 2016 sur la lutte contre le racisme, l'antisémitisme et la xénophobie. La Documentation française.

Condon, S., Lieber, M. \& Maillochon, F. (2005). Insécurité dans les espaces publics : comprendre les peurs féminines. Revue française de Sociologie, 46,(2), 265-294.

Cordazzo, P. (2016). Les étudiants vulnérables : entre renoncements et travail contraint. In J.F. Giret, C. Van de Velde \& É. Verley (Eds.), Les vies étudiantes : Tendances et inégalités (183-192). Études et Recherches. Paris : La documentation Française.

Coulon, A. (2005 [1997]). Le métier d'étudiant : l'entrée dans la vie universitaire. Paris : Éditions Economica/Anthropos.

Debarbieux, E. (2004). Les enquêtes de victimation en milieu scolaire : leçons critiques et innovations méthodologiques. Déviance et Société, 28(3), 317-333.

Dell'Umbria, A. (2006). Histoire universelle de Marseille. De l'an mil à l'an deux mille. Marseille : Agone.

Donzel, A. \& Bresson T. (2007). La métropole marseillaise et ses fractures. In P. Langevin \& J.-C. Juan (Eds.), Marseille, une métropole entre Europe et méditerranée (93-112). Paris : La Documentation Française.

Dubet, F., Filatre, D., Merrien, F.-X., Sauvage, A. \& Vince, A. (1994). Universités et ville. Paris : L'Harmattan.

Duprez, D. \& Hedli M. (1992). Le mal des banlieues ? Sentiment d'insécurité et crise identitaire. Paris : L'Harmattan. 
Eckert, H. \& Primon, J.-L. (2011). Enquêter sur le vécu de la discrimination. Introduction. Agora débats/jeunesses, 57(1), 54-61.

Eicher, J.-C. \& Gruel, L. (1996). Le financement de la vie étudiante. Paris : La documentation française (Cahier de l'OVE).

Felouzis, G. (2001). La condition étudiante. Paris : PUF.

Ferry, O. \& Tenret, E. (2017). À la tête de l'étudiant.e? Les discriminations perçues dans l'enseignement supérieur. OVE Infos.

Figgie Report (1980). America Afraid. The Figgie Report on Fear of Crime: New York.

Fleury DeVoe, J. \& Bauer, L. (2011). Student Victimization in U.S. School: Results From 2009 School Crime Supplement to the Natioanal Crime Victimization Survey. National Center for education statistics, nov.

Hart, T. \& Miethe, T. (2011). Violence Against College Students and Its Situational Contexts: Prevalence, Patterns, and Policy Implications. Victims \& Offenders, 6 (2), 157-180.

Insee (2016). Recensement de la population 2014 au 01/01/2016.

Kerbrat-Orecchioni, C. (1990). Théorie des faces et analyse conversationnelle. In Le parler frais d'Erving Goffman. Paris : Éditions de Minuit.

Koss, Mary P., Dinero, Thomas E., Seibel, Cynthia A. \& Cox, Susan L. (March 1988). Stranger and acquaintance rape: are there differences in the victim's experience? Psychology of Women Quarterly, 12(1), 1-24.

Lapeyronnie, D. \& Marie, J.-L. (1992). Campus blues. Les étudiants face à leurs études. Paris : Seuil.

Lepoutre, D. (1997). Cour de banlieue. Codes, rites et langages. Paris : Odile Jacob.

Lesné, M. \& Simon, P. (2012). La mesure des discriminations dans l'enquête « Trajectoires et Origines $\gg$. Document de travail, $\mathrm{n}^{\circ} 184$. Ined.

Levy-Garboua, L. (1976). Les demandes des étudiants ou les contradictions de l'université de masse. Revue française de sociologie, XVII, 53-80.

McInnis, C. (2004). Studies of Student Life: an overview. European Journal of Education, Vol. 39, n 4, 383-394.

MESRI [Ministère de l'enseignement supérieur, de la recherche et de l'innovation] (2017). L'état de l'Enseignement supérieur et de la Recherche en France. 49 indicateurs. Paris : MESRI - Direction générale de l'enseignement supérieur et de l'insertion professionnelle Direction générale de la recherche et de l'innovation.

Moïse, C. (2011). Gros mots et insultes des adolescents. La lettre de l'enfance et de l'adolescence, 1, 29-36.

Mucchielli, L. (2004). L'impossible constitution d'une discipline criminologique en France : cadres institutionnels, enjeux normatifs et développements de la recherche des années 1880 à nos jours. Criminologie, 37(1), 13-42.

Mucchielli, L. (2011). L'invention de la violence. Des peurs, des crimes, des faits. Paris : Fayard.

Mucchielli, L. (2015). "Marseille bashing ?" Remarques sur la stigmatisation d'une ville réputée exceptionnellement violente. In C. Dargère et $\mathrm{S}$. Heas (Eds.), La chute des masques. De la construction à la révélation du stigmate (179-190). Grenoble : Presses Universitaires de Grenoble.

Mucchielli, L. (2014). Sociologie de la délinquance. Paris : Armand Colin.

Mucchielli, L., Raquet, É., Saladino, C. \& Raffin, V. (2014). La Provence, terre de violence : Les présupposés culturalistes à l'épreuve de l'analyse statistique. Déviance et Société, 38(2), 199-225.

Mucchielli, L. \& Raquet, É. (Eds.) (2016). Délinquance police, justice. Enquêtes à Marseille et en région PACA. Marseille : Presses Universitaires de Provence.

Newman, O. (1972). Defensible Space. Crime Prevention Through Urban Design. New York : Macmillan. 
Peraldi, M. (Eds.), Duport, C. \& Samson, M. (2015). Sociologie de Marseille. Paris : La Découverte.

Pottier, M. \& Robert, P. (1997). "On ne se sent plus en sécurité". Délinquance et insécurité. Une enquête sur deux décennies. Revue française de science politique, 47(6), 707-740.

Pottier, M.-L., Robert, Ph. \& Zauberman, R. (2002). Victimation et insécurité en Île-deFrance. Les résultats de la première enquête (2001). Rapport final, Paris/Guyancourt : IAURIF/CESDIP.

Pujol, P. (2016). La fabrique du monstre. Paris : Broché.

Quintero, O. (2013). Racismo y discriminación en la universidad: lecturas cruzadas de las sociedades francesa y colombiana a partir de la experiencia vivida por estudiantes negros en París y Bogotá. Université Rennes 2 : thèse de doctorat.

Rea, A. \& Tripier, M. (2008). Sociologie de l'immigration. Paris : La Découverte.

Rizk, C. (2011). Violences physiques ou sexuelles au sein du ménage, Description par les personnes de 18 à 75 ans se déclarant victimes des suites et des conséquences des actes subis. INHESJ/ONDRP, Repères, ${ }^{\circ} 15$.

Robert, P. \& Zauberman, R. (2011). Mesurer la délinquance. Paris : Presses de Sciences Po.

Robert, P. \& Zauberman, R. (2017). Du sentiment d'insécurité à l'état sécuritaire. Lormont : Le Bord de l'eau.

Roché, S. (1993). Le sentiment d'insécurité. Paris : PUF.

Rosier L., (2009 [2006]). Petit traité de l'insulte. Labor : Loverval.

Taylor, R. B., Shumaker, S. \& Gottfredson, S. D. (1985). Neighborhood level links between physical features and local sentiments. Deterioration fear and confidence of crime. Journal of architectural and planning research, 2, 261-275.

Simon J. (1994). In the Place of the Parent: Risk Management and the Government of Campus Life". Social and Legal Studies, 3(1), 15-45.

Sloan J., Fisher B. \& Cullen F. (1997). Assessing the Student Right-to-Know and Campus Security Act of 1990: An Analysis of the Victim Reporting Practices of College and University Students/Sloan, Crime and Delinquency, 43(2), 146-168.

Warshaw, R. (1994 [1988]). I Never Called It Rape. New York: Harper.

Walklate, S. (11/1994). Risk and criminal victimization: A modernist dilemma? Paper presented at the annual conference of the American Society of Criminology, Miami.

Zauberman, R. (2015). Les enquêtes de victimation : Une brève histoire, quelques usages. Idées économiques et sociales, 181(3), 8-21.

Zauberman, R., Robert, P., Beck, F. \& Névanen, S. (2013). Mesurer l'implication des jeunes dans la violence. Déviance et Société, 37(1), 89-115. 